\title{
Effects of Vasoactive Intestinal Polypeptide (VIP), Secretin and Gastrin on Insulin Secretion in the Mouse
}

\author{
B. Ahrén and I. Lundquist \\ Department of Pharmacology, University of Lund, Lund, Sweden
}

Summary. The in vivo effects of vasoactive intestinal polypeptide (VIP), secretin and two different molecular forms of gastrin, gastrin 17 and pentagastrin, on basal and stimulated insulin secretion have been investigated in the mouse. All these peptides induced a moderate dose-dependent increase in basal insulin secretion. The different polypeptides showed complex effects on insulin release stimulated by glucose, the cholinergic agonist carbachol or the $\beta$ adrenergic agonist L-isopropylnoradrenaline (LIPNA), these effects being dependent on the nature of the secretagogue. VIP and secretin both potentiated glucose-induced insulin release. Secretin inhibited insulin secretion induced by carbachol and LIPNA, whereas VIP potentiated L-IPNA-induced insulin secretion and had no influence on the effect of carbachol. Gastrin 17 and pentagastrin did not affect glucose- or carbachol-induced insulin release, whereas they inhibited L-IPNA-induced insulin secretion. The results suggest that VIP, secretin and gastrin display their effects on insulin secretion through different mechanisms. The results indirectly suggest the existence of separate insulin secretory pathways which operate differently, or at least partly differently, after glucose stimulation, cholinergic stimulation, and $\beta$-adrenergic stimulation.

Key words: VIP, secretin, gastrin, basal insulin secretion, stimulated insulin secretion, cholinergic stimulation, $\beta$-adrenergic stimulation, glucose stimulation, in vivo, mouse.

Several gastrointestinal endocrine polypeptides are known to affect insulin secretion $[1,2]$. Oral intake of glucose is followed by a greater insulin release than
IV glucose administration, despite a lower blood glucose level. This potentiated response seems to be due to the release of gastro-intestinal peptides, the socalled incretin effect [3]. Peptides produced by intrapancreatic cells, endocrine and neural, may also regulate insulin secretion by a paracrine effect [4]. Some of these polypeptides show similarities in chemical structure and can therefore be grouped into two families [5], the glucagon family including glucagon, vasoactive intestinal polypeptide (VIP), secretin, and gastric inhibitory polypeptide (GIP), and the gastrin family including cholecystokinin (CCK) and gastrin.

Recently it was demonstrated that some of the newly discovered gastrointestinal polypeptides interfere with the insulin secretory mechanisms in a complex manner, the effects on stimulated insulin secretion being highly dependent on the nature of the secretagogue [6]. The aim of the present investigation was to characterise further the effect of gastrointestinal polypeptides on basal and stimulated insulin release, and to compare effects of peptides belonging to the same polypeptide family with each other and with members of the other family. For this purpose we selected VIP and secretin on one hand and two different molecular forms of gastrin on the other. The in vivo insulin-releasing properties of these polypeptides were investigated under identical experimental conditions in the mouse.

\section{Materials and Methods}

\section{Animals}

Female mice of the NMRI strain (Laboratory Animal Breeding, Laven, Denmark), weighing 25-35 g, were used. The animals were kept on a standard pellet diet (Astra-Ewos, Södertälje, Sweden) with tap water ad libitum before and throughout the experiments. 


$$
\text { V.I.P. }
$$

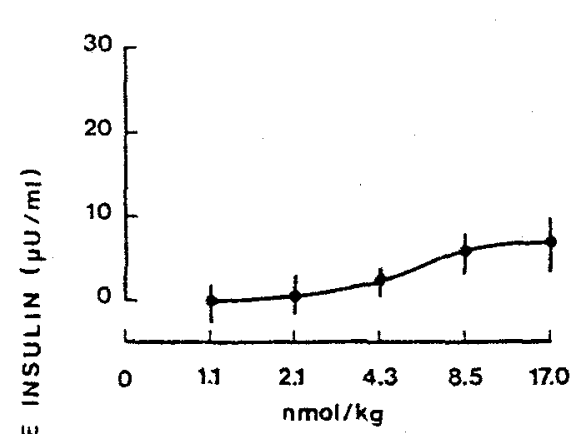

PENTAGASTRIN

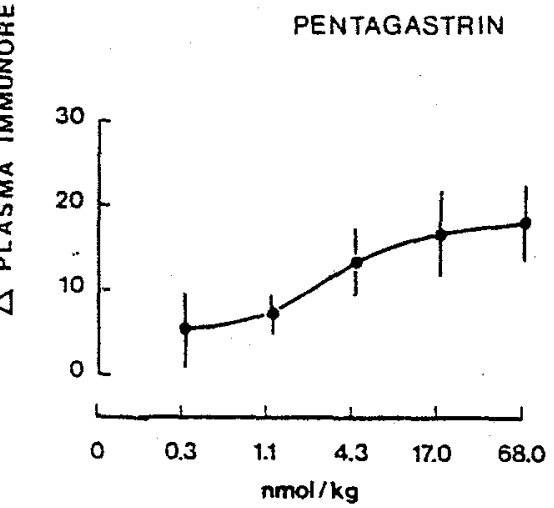

SECRETIN

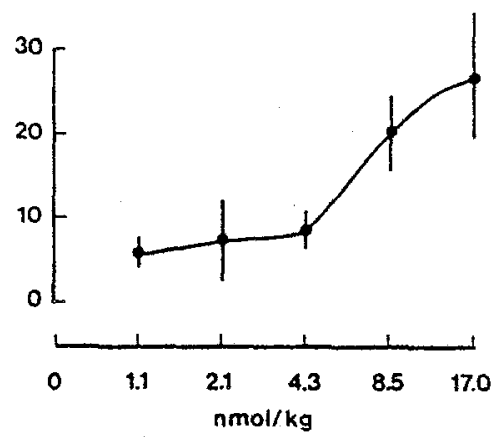

GASTRIN 17

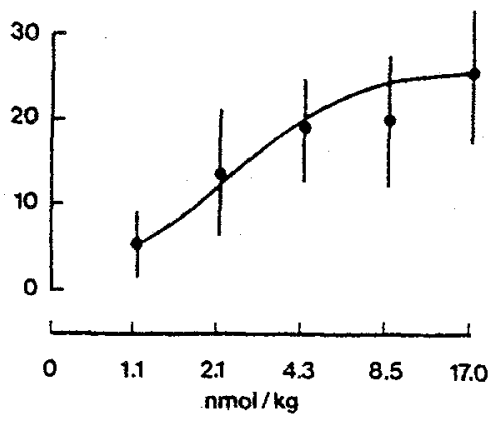

Fig. 1. Dose-response relationships between dose of vasoactive intestinal polypeptide (VIP) secretin, pentagastrin, and gastrin 17 , and insulin release in NMRI mice. Plasma concentrations of immunoreactive insulin were measured in samples taken 2 min aiter IV injection of the polypeptides. Mean \pm SEM is shown. Each group consisted of 10-16 animals with the exception of the VIP-experiments when 18-30 mice were used

\section{Drugs}

Pure porcine VIP and pure porcine secretin were kindly donated by Professor V. Mutt, Karolinska Institutet, Stockholm, Sweden. Pentagastrin (Peptavlon) was obtained from ICI Ltd., Macclesfield, England. Synthetic human gastrin 17 was from Bachem Inc., Torrance, Calif., USA. All peptides were dissolved in $0.154 \mathrm{~mol} / 1$ saline with the addition of $1 \mathrm{~g} / \mathrm{l}$ gelatine to avoid adsorption.

D-gilucose and carbachol (British Drug Houses Ltd., Poole, England) and L-isopropylnoradrenaline (L-IPNA) (Hässle AB, Mölndal, Sweden) were dissolved in $0.154 \mathrm{~mol} / \mathrm{l}$ saline.

\section{Protocols}

1. Effects on Basal Insulin Secretion. The peptides were administered IV through a tail vein, in a volume of $10 \mu \mathrm{l} / \mathrm{g}$ body weight. Control animals were injected with $0.154 \mathrm{~mol} / 1$ saline. After 2 or $5.5 \mathrm{~min} 250 \mu \mathrm{l}$ blood was drawn by orbital puncture [7]. The mice were conscious throughout the experiments.

II. Effects on Stimulated Insulin Secretion. The peptides were injected IV, $5 \mu \mathrm{l} / \mathrm{g}, 15 \mathrm{~s}$ prior to a rapid IV injection of $5 \mu \mathrm{l} / \mathrm{g}$ of either D-glucose, carbachol or L-IPNA. Control animals were injected with $0.154 \mathrm{~mol} / \mathrm{l}$ saline and one of the secretagogues, or with saline alone. This sequence of the injections was chosen in order to mimic the anticipated humoral insulin releasing influence, when gut peptides released following a meal may reach the islet cells before the nutrients [6]. Two minutes (glucose and carbachol) or $5.5 \mathrm{~min}$ (L-IPNA) after the last injection blood was collected as above. Previous experiments have shown that the maximal concentration of immunoreactive insulin in mouse plasma following a rapid IV injection of these secretagogues was achieved after 2 (glucose and carbachol) and 5.5 (L-IPNA) min, respectively. The secretagogues were administered in doses giving half-maximal insulin secretory responses. These doses were $2.8 \mathrm{mmol} / \mathrm{kg}$ (glucose), $160 \mathrm{nmol} / \mathrm{kg}$ (carbachol) and $340 \mathrm{nmol} / \mathrm{kg}$ (L-IPNA).

\section{Determination of Insulin and Glucose}

Plasma immunoreactive insulin concentrations (IRI) were measured by radioimmunoassay [8] using ${ }^{125}$ I-Iabelled porcine insulin and guinea pig anti-porcine-insulin, with porcine insulin as standard. Plasma glucose concentrations were measured with a glucose oxidase method [9].

\section{Statistics}

The results are presented as mean \pm SEM. Student's $t$-test was used to test significance.

\section{Results}

\section{Effects of the Polypeptides on Basal Insulin Secretion}

VIP, secretin, gastrin 17 and pentagastrin all induced stimulation of insulin secretion in a dose-dependent manner 2 min after injection (Fig, 1). At the highest 
dose levels studied they increased the plasma IRI concentrations by $8-30 \mathrm{mU} / \mathrm{l}$. Plasma IRI did not differ from control values $5.5 \mathrm{~min}$ after hormone injection.

\section{Effects of the Polypeptides on Stimulated Insulin Secretion}

a) VIP (Fig. 2). Injection of VIP, $4.25 \mathrm{nmol} / \mathrm{kg}$ (the threshold dose for stimulation of basal insulin secretion), IV $15 \mathrm{~s}$ prior to $I V$ injection of one of the secretagogues induced a potentiation of both glucose- and L-IPNA-stimulated insulin secretion, while carbachol-induced insulin release was unaffected. Glucose-stimulated insulin secretion was inreased by $30 \%(\mathrm{p}<0.05)$, and L-IPNA-induced insulin release by $65 \%(\mathrm{p}<0.01)$, by VIP.

b) Secretin (Fig. 3). IV injection of secretin, $4.25 \mathrm{nmol} / \mathrm{kg}, 15 \mathrm{~s}$ prior to IV injection of glucose resulted in a potentiation of glucose-induced insulin release. Secretin was more potent than VIP, potentiating the insulin releasing effect of glucose by $90 \%$ $(p<0.001)$. In contrast to VIP, secretin inhibited the effects of both carbachol and L-IPNA. Carbacholinduced insulin secretion was inhibited by $35 \%$ (p $<0.01$ ) and L-IPNA-stimulated insulin release by $30 \%(\mathrm{p}<0.05)$.

c) Gastrin 17(Fig. 4) and Pentagastrin (Fig. 5). These peptides exerted identical effects on stimulated insulin release. With IV injection in a dose of $4.25 \mathrm{nmol} /$ $\mathrm{kg} 15 \mathrm{~s}$ prior to injection of each of the secretagogues neither of them changed the insulin secretory response to glucose or carbachol. However, both peptides inhibited the L-IPNA-induced insulin secretion, gastrin 17 by $35 \%(\mathrm{p}<0.05)$ and pentagastrin by $20 \%(\mathrm{p}<0.05)$.

\section{Plasma Glucose Concentrations}

Plasma glucose concentrations were $8.5 \pm 0.4 \mathrm{mmol} /$ 1 in mice not receiving glucose. There was no difference in plasma glucose levels between the groups. Thus none of the polypeptides, nor carbachol and LIPNA influenced the plasma glucose during the timeperiod studied. Two minutes after glucose injection the plasma glucose concentrations were $15.8 \pm$ $1.1 \mathrm{mmol} / 1$. There was no difference between the glucose-treated groups.

\section{Discussion}

The 28 amino acid peptide VIP is presumed to occur in neurones in the gut and pancreas and it has been suggested to be a neurotransmitter $[10-13]$. The 27

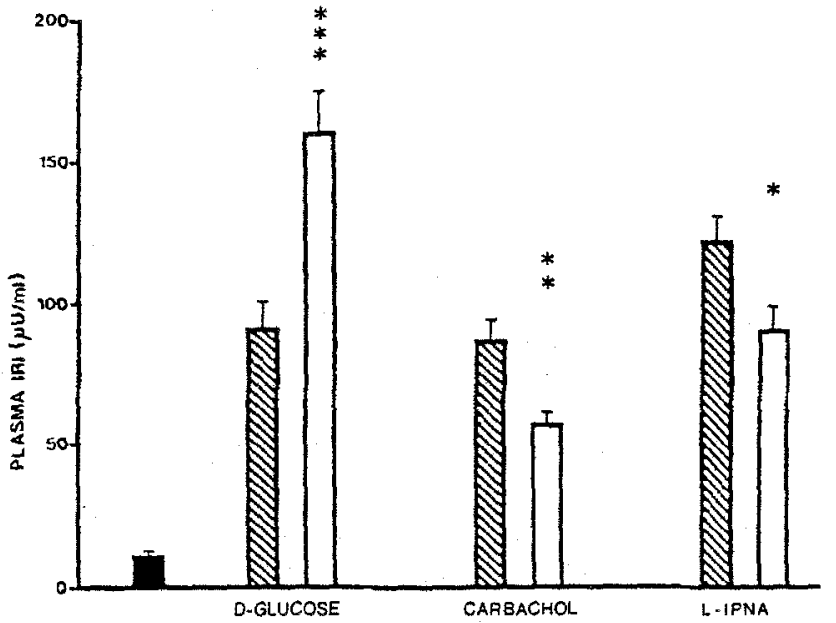

Fig. 3. Effect of secretin on acute insulin release stimulated by D-glucose, carbachol, or L-isopropylnoradrenaline (L-IPNA). Saline $(0.154 \mathrm{moi} / 1)$ (hatched columns), or secretin $(4.25 \mathrm{nmol}$ $\mathrm{kg}$ ) (open columns) was given IV $15 \mathrm{~s}$ prior to half-maximal doses of D-glucose $(2.8 \mathrm{mmol} / \mathrm{kg})$, carbachol $(160 \mathrm{nmol} / \mathrm{kg})$, or L-IPNA $(340 \mathrm{nmol} / \mathrm{kg})$. Control animals received saline $(0.154 \mathrm{~mol} / \mathrm{l})+$ saline $(0.154 \mathrm{~mol} / \mathrm{l})$ (black column). Bars indicate SEM. Asterisks indicate probability level of random difference for saline $v s$ secretin treated groups. ${ }^{*} p<0.05,{ }^{* *} p<0.01,{ }^{* * *} p<0.001$. Each group consisted of $22-45$ mice 


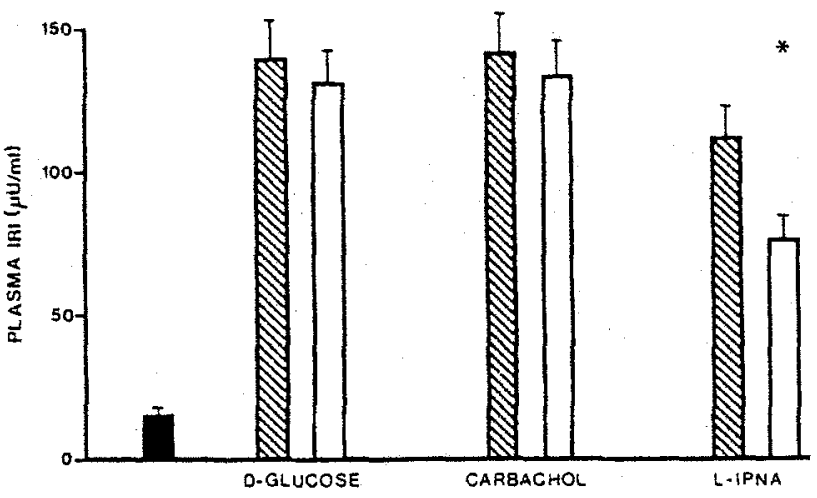

Fig. 4. Effects of gastrin 17 on acute insulin release stimulated by D-glucose, carbachol, or L-isopropylnoradrenaline (L-IPNA). Saline $(0.154 \mathrm{~mol} / \mathrm{l})$ (hatched columns) or gastrin $17(4.25 \mathrm{nmol} /$ $\mathrm{kg}$ ) (open columns) was injected IV $15 \mathrm{~s}$ prior to half-maximal doses of $D$-glucose $(2.8 \mathrm{mmol} / \mathrm{kg})$, carbachol $(160 \mathrm{nmol} / \mathrm{kg})$, or L-IPNA $(340 \mathrm{nmol} / \mathrm{kg})$. Control animals received saline $(0.154$ $\mathrm{mol} / 1)+$ saline $(0.154 \mathrm{~mol} / 1)$ (black column). Bars indicate SEM. Asterisks indicate probability level of random difference for saline vs gastrin 17 treated groups. ${ }^{*} p<0.05$. Each group consisted of 15-33 mice

amino acid peptide secretin has been shown to occur in endocrine cells in the small intestine [14]. Chemically VIP and secretin resemble glucagon and GIP, and these polypeptides have been grouped in one family [5].

VIP has been shown to have a stimulatory action on insulin release in the'dog and pig [15-18] and in the perfused cat pancreas [19], but is reported to have no insulin releasing activity in vivo in the rat [20]. Secretin seems to stimulate insulin secretion in high doses in man $[1,2,21-23]$ and while augmenting glucose-induced insulin release it had no influence on the effect of other secretagogues [22]. In doses that reproduce the level of circulating secretin, however, there was no effect on glucose-induced insulin release [24].

In the present study we have demonstrated a slight dose-dependent increase of basal plasma insulin levels after administration of VIP or secretin, and these two peptides also potentiated glucose-induced insulin secretion. It is notable that the insulin-releasing activity of the two polypeptides was very weak compared to the effect of glucose and it seems unlikely that they function as important modulators of basal insulin release. In equimolar doses we found secretin to be more potent than VIP in stimulating basal insulin secretion, and also in its ability to potentiate glucose-induced insulin secretion.

VIP and secretin differed in their effects on carbachol- and L-IPNA-induced insulin release. While VIP enhanced the response to $\beta$-adrenergic stimula-

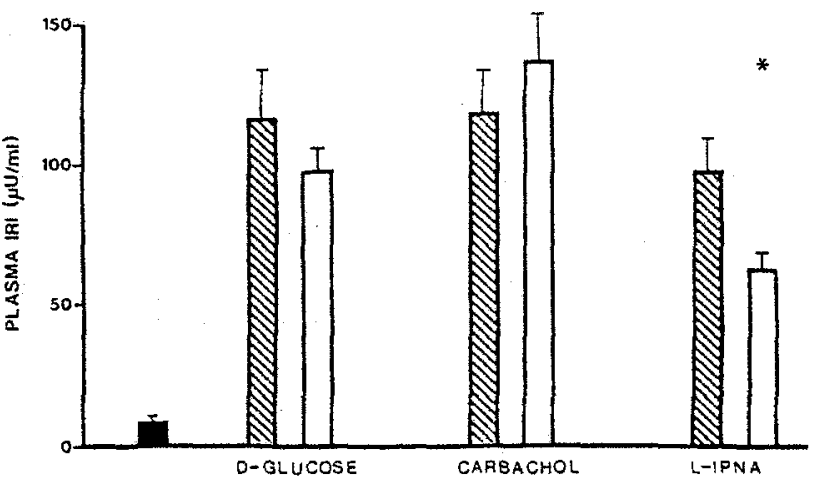

Fig. 5. Effect of pentagastrin on acute insulin release stimulated by D-glucose, carbachol, or L-isopropylnoradrenaline (L-IPNA). Saline $(0.154 \mathrm{~mol} / 1)$ (hatched columns) or pentagastrin $(4.25$ $\mathrm{nmol} / \mathrm{kg}$ ) (open columns) was injected IV $15 \mathrm{~s}$ prior to half-maximal doses of D-glucose $(2.8 \mathrm{mmol} / \mathrm{kg})$, carbachol $(160 \mathrm{nmol} / \mathrm{kg})$, or L-IPNA ( $340 \mathrm{nmol} / \mathrm{kg}$ ). Control animals received saline $(0.154 \mathrm{~mol} / \mathrm{l})+$ saline $(0.154 \mathrm{~mol} / \mathrm{l})$ (black column). Bars indicate SEM. Asterisks indicate probability level of random difference for saline us pentagastrin treated groups. ${ }^{*} p<0.05$. Each group consisted of 10-19 mice

tion it had no effect on cholinergically induced insulin secretion. Secretin, on the contrary, inhibited the effects of these two secretagogues. It is thus reasonable to assume that in the mouse VIP and secretin interact with different receptors on the insulin cell. From studies in liver and fat cells it was suggested that the two peptides stimulate the same receptors [25], whereas on pancreatic acinar cell membranes from the guinea-pig two kinds of VIP/secretin-sensitive receptors have been described [26]. These receptors had different affinities but the same expression for VIP and secretin, respectively. Since the present study demonstrates that some of the effects of VIP and secretin differed it can be suggested that the peptides stimulated less related receptors on the insulin cells.

Gastrin is chemically heterogenous and occurs in several different molecular forms [27]. It has been localized to endocrine cells in the antrum and proximal duodenum $[28,29]$. Furthermore it has been demonstrated to occur in endocrine cells in the pancreatic islets during the neonatal period [30]. Recently, gastrin-immunoreactivity was also described in nerves in several organs including the pancreas $[13,31]$.

A stimulatory effect on basal as well as on glucose-induced insulin release after administration of gastrin to man and dog has previously been reported $[1,2,21,32-34]$. Generally, higher plasma levels of gastrin than are seen under physiological conditions are necessary to obtain an insulin-releasing effect [1]. 
We found that both gastrin 17 and pentagastrin stimulate basal insulin release in a dose-dependent manner, but their potency was low. The results suggest that circulating gastrin is of no or little importance for basal insulin release in the mouse.

Gastrin 17 and pentagastrin were found to exert identical effects on stimulated insulin release, suggesting that they interact with the same receptors. Both peptides inhibited L-IPNA-induced insulin release, while showing no influence on glucose- or carbachol-stimulated secretion of insulin. This pattern of effects differed from that of VIP and secretin. It has been suggested that secretin and gastrin act on the same receptors [35] but since the effects on insulin release of gastrin clearly differed from that of secretin, the results of the present study do not favour this hypothesis.

The physiological relevance of these polypeptides for insulin secretion cannot be deduced from this study. Our results show, however, that insulin secretion is influenced by the gastrointestinal polypeptides in a complex way. Interaction of all polypeptides with one type of receptors on the insulin cell cannot explain the results. Furthermore, the effects of the polypeptides on stimulated insulin secretion are highly dependent on the nature of the secretagogue. The results indirectly suggest that glucose, cholinergic agonists, and $\beta$-adrenergic agonists, respectively, stimulate insulin release by activation of separate or partly separate pathways. The polypeptides could be affecting the receptors of the secretagogues, or initiating intracellular events interacting with those of the secretagogues.

Acknowledgements. The technical assistance of Asa Amilon, Lena Kvist and Peter Okmark is gratefully acknowledged. This study was supported by grants from the Swedish Medical Research Council $(04 \mathrm{P}-4289,14 \mathrm{X}-4289)$ and from the Medical Faculty, University of Lund, Lund, Sweden.

\section{References}

1. Rehfeld JF (1972) Gastrointestinal hormones and insulin secretion. Scand J Gastroenterol 7: 289-292

2. Brown JC, Otte SC (1978) Gastrointestinal hormones and the control of insulin secretion. Diabetes 27: 782-787

3. Creutzfeldt W (1979) The incretin concept today. Diabetologia 16: $75-85$

4. Unger RH, Orci L (1977) Possible roles of the pancreatic Dcell in the normal and diabetic states. Diabetes 26: 241-244

5. Dockray GJ (1977) Molecular evolution of gut hormones: application of comparative studies on the regulation of digestion. Gastroenterology 72: 344-358

6. Lundquist I, Sundler $F$, Ahrén $B$, Alumets J, Håkanson R (1979) Somatostatin, pancreatic polypeptide, substance $P$, and neurotensin: Cellular distribution and effects on stimulated insulin secretion in the mouse. Endocrinology 104: 832-838

7. Rerup C, Lundquist I (1966) Blood glucose level in mice. I.
Evaluation of a new technique of multiple serial sampling. Acta Endocrinol (Kbh) 52: 357-367

8. Heding $L$ (1966) A simplified insulin radioimmunoassay method. In: Donato L, Milhaud G, Sirchis J (eds) Labelled proteins in tracer studies. Euratom, Brussels, p 345-350

9. Bruss ML, Black AL (1978) Enzymatic microdetermination of glycogen. Anal Biochem 84: 309-312

10. Larsson L-I, Fahrenkrug J, Schaffalitzky de Muckadell O, Sundler F, Håkanson R, Rehfeld JF (1976) Localization of vasoactive intestinal polypeptide (VIP) to central and peripheral neurons. Proc Natl Acad Sci USA 73: 3197-3200

11. Sundler F, Alumets J, Håkanson R, Fahrenkrug J, Schaffalitzky de Muckadell O (1978) Peptidergic (VIP) nerves in pancreas. Histochemistry 55: 173-176

12. Fahrenkrug J (1979) Vasoactive intestinal polypeptide: measurement, distribution and putative neurotransmitter function. Digestion 19: 149-169

13. Larsson L-I, Rehfeld JF (1979) Peptidergic and adrenergic innervation of pancreatic ganglia. Scand J Gastroenterol 14: $433-437$

14. Larsson L-I, Sundler F, Alumets J, Håkanson R, Schaffaiitzky de Muckadell OB, Fahrenkrug J (1977) Distribution, ontogeny and uitrastructure of the mammalian secretin cell. Cell Tissue Res 181: 361-368

15. Lindkear Jensen S, Fahrenkrug J, Holst JJ, Vagn Niesen O, Schaffalitzky de Muckadell $O B$ (1978) Secretory effects of vasoactive intestinal polypeptide (VIP) on the isolated perfused porcine pancreas. Am J Physiol 235: E387-E391

16. Ohneda A, Ishii S, Horigome K, Chiba $M$, Sakai $T$, Kai $Y$, Watanabe K, Yamagata S (1977) Effect of intrapancreatic administration of vasoactive intestinal peptide upon the release of insulin and glucagon in dogs. Horm Metab Res 9: $447-452$

17. Kaneto A, Kaneko T, Kajinuma H, Kosaka K (1977) Effect of vasoactive intestinal polypeptide infused intrapancreatically on glucagon and insulin secretion. Metabolism 26: 781-786

18. Makhlouf GM, Yau WM, Zfass AM, Said SI, Bodanszky M (1978) Comparative effects of synthetic and natural vasoactive intestinal peptide on pancreatic and biliary secretion and on glucose and insulin blood levels in the dog. Scand J Gastroenterol 13: 759-765

19. Schebalin M, Said SI, Makhlouf GM (1977) Stimulation of insulin and glucagon secretion by vasoactive intestinal peptide. Am J Physiol 232: E197-E200

20. Turner DS, Etheridge L, Marks V, Brown JC, Mutt V (1974) Effectiveness of the intestinal polypeptides IRP, GIP, VIP and motilin on insulin release in the rat. Diabetologia 10: 459-463

21. Unger RH, Ketterer H, Dupré J, Eisentraut AM (1967) The effects of secretin, pancreozymin, and gastrin on insulin and glucagon secretion in anesthetized dogs. J Clin Invest 46: $630-645$

22. Lerner RL (1977) The augmentation effect of secretin on the insulin responses to known stimuli: specificity for glucose. $J$ Clin Endocrinol Metab 45: 1-9

23. Enk B (1976) Secretin induced insulin response. Acta Endocrinol (Kbh) 82: 312-317

24. Fahrenkrug J, Schaffalitzky de Muckadell OB, Kühl C (1978) Effect of secretin on basal- and glucose-stimulated insulin secretion in man. Diabetologia 14:.229-234

25. Desbuquois B, Landat MM, Landat $\mathrm{Ph}$ (1973) Vasoactive intestinal polypeptide and glucagon: stimulation of adenylate cyclase activity via distinct receptors in lever and fat cell membranes. Biochem Biophys Res Commun 53: 1187-1194

26. Christophe JP, Conlon TP, Gardner JD (1976) Interaction of porcine vasoactive intestinal peptide with dispersed pancreatic aciner cells from guinea pig. Binding of radioiodinated peptide. J Biol Chem 251: 4629-4634 
27. Rehfeld JF, Stadil F, Malmström J, Miyata M (1975) Gastrin heterogeneity in serum and tissue: a progress report. In: Thompson JC (ed) Gastrointestinal hormones. University of Texas Press, Austin London, p 43-58

28. McGuigan JE (1968) Gastric mucosal intracellular localization of gastrin by fluorescence. Gastroenterology 55:315-327

29. Dubois PM, Paulin C, Chayvialle JA (1976) Identification of gastrin-secreting cells and cholecystokinin-secreting cells in the gastointestinal tract of the human fetus and adult man. Cell Tissue Res 175: 351-356

30. Larsson L-I, Rehfeld JF, Sundler F, Håkanson R (1976) Pancreatic gastrin in foetal and neonatal rats. Nature 262: 609-610

31. Uvnäs-Wallensten K, Rehfeld JF, Larsson L-I, Uvnäs B (1977) Heptadecapaptide gastrin in the vagal nerve. Proc Natl Acad Sci USA 74: 5707-5710

32. Rehfeld JF (1971) Effect of gastrin and its C-terminal tetrapeptide on insulin secretion in man. Acta Endocrinol (Kbh) 66: $169-176$

33. Rehfeld JF, Stadil F (1973) The effect of gastrin on basal- and glucose-stimulated insulin secretion in man. J Clin Invest 52 : 1415-1426

34. Kuzuya T, Kajinuma H, Sando H, Hayashi M, Ide T, Kosaka K (1978) Comparison of the early time courses of the release of insulin that follow injections of tetragastrin, tolbutamide, xylitol, and glucose into the pancreatic artery of dogs. Diabetes 27:1189-1195

35. Grossman MI (1970) Gastrin, cholecystokinin and secretin act on one receptor. Lancet I: 1088-1089

Received: January 20, 1980,

and in revised form: July 7,1980

Dr. Bo Ahrén

Department of Pharmacology

University of Lund

Sölvegatan 10

S-223 62 Lund, Sweden 